Trachnology

\section{Encouraging Environmental and Community Stewardship with Trained Extension Volunteers}

\author{
William T. Hlubik' and Richard B. Weidman ${ }^{2}$
}

Additional index words. community beautification, community gardening, Master Gardener, people-plant interaction

Summary. In 1993, a modification of the Master Gardener volunteer program was created to focus on ecological principles for environmentally sound gardening. The new program is called the Master Gardener-Environmental and Community Stewardship (MGECS) program and addresses important environmental concerns in Middlesex County, N.J. Program participants receive more than 100 hours of training in horticultural and ecological principles and are required to share their knowledge with others through volunteer activities monitored by cooperative extension staff. Volunteers encourage home comporting, recycling of grass clippings, proper fertilization techniques, and leasttoxic pest control in the home landscape and garden. Trained volunteers have helped more than 16,000 people during the past 2 years through lectures, demonstrations, telephone contacts, and newspaper articles. Since the MGECS program began in 1993, the number of volunteer hours per person during the first year has increased by $30 \%$ compared to the traditional Master Gardener program offered from 1989 to 1992 . This new program is an effective model to encourage practical environmental stewardship through community volunteer action.

${ }^{1}$ Assistant professor and county agricultural and resource management agent for Rutgers Cooperate Extension of Middlsex County, N.J.

${ }^{2}$ Agricultural program associate for Rutgers Cooperative Extension of Middlesex County, N.J.

Tbe cost of publishing this paper was defrayed in part by the payment of page charges. Under postal regulations, this paper therefore must be hereby marked advertisement solely to indicate this fact.
7 he concept of stewardship implies individual action and requires people to move beyond adversarial responses and accept personal responsibility for the fate of their community and physical environment (Hlubik and Betros, 1992). The condition of the physical environment plays a very important role on how people respond to that environment and to each other (Stainbrook, 1973). One way to encourage environmental stewardship may be to improve the physical surroundings of neighborhoods with community based plantings of trees, flowers, and vegetable gardens. Plantings may help establish a greater connection among community members and their surrounding physical environment.

This paper describes the Master Gardener-Environmental and Community Stewardship (MGECS) program. The purpose of the program is to capitalize $\mathrm{cm}$ humankind's intrinsic affinity for plants and gardening to encourage volunteer service that promotes healthy communities and environments. The traditional Master Gardener (MG) program provided the foundation for the new MGECS program.

\section{Master gardeners}

Master gardeners are volunteers that receive technical training and guidance from the U.S. Dept. of AgricultureCooperative State Research-Education and Extension Service (CSREES) that exists in many counties in the United States. More than 50,000 people in the United States have enrolled in the MG volunteer program (Master Gardener International Corp.,1991).

The MG program has successfully encouraged valuable community volunteer projects, including horticultural therapy programs in more than 21 states (Flagler, 1992) and hundreds of community gardening and beautification projects (Bonham, 1992; Patel, 1992). In addition to gardening and beautification projects, master gardeners have also helped CSREES establish successful educational programs that promote environmental stewardship through sound cultural practices in the landscape. In Virginia, more than 200 MG volunteers provided information on proper nutrient management to more than 1200 residents in the Chesapeake Bay area to reduce nonpoint source pollution (Relf and McKissack, 1992).

\section{The MGECS program}

A written survey in 1992 revealed that $95 \%$ of the 30 participants in that year's program believed that it was important to cover environmental issues in the MG program. In addition, many county residents in contact with cooperative extension staff and volunteers have expressed concern regarding environmental problems such water pollution and the solid-waste crisis.

In response to these concerns, cooperative extension staff redesigned and renamed the traditional MG program to emphasize practical methods for program volunteers to practice and encourage greater environmental stewardship in their homes and communities. The new MGECS program, established in 1993, differs from other MG programs in that it integrates scientifically based horticultural training with ecological principles that encourage practical environmental stewardship. One-third of the 30 classes and field trips are devoted to ecological principles.

The primary purpose of the MGECS program is to 
provide a model that encourages individuals to adopt practices that promote environmental stewardship. The program curriculum emphasizes gardening and landscaping techniques that minimize negative impacts on the human community and natural environment. This includes classes that explain and encourage the following: a) integrated pest management; b) low-water landscaping; c) proper use, storage, and disposal of pesticides and other toxic materials found around the home; and d) home comporting and recycling to reduce solid-waste problems. In addition, the volunteer service component of the program requires participants to help establish community projects that encourage environmental stewardship.

Each year, 20 to 30 students receive $100 \mathrm{~h}$ of classroom instruction combined with field trips and workshops for 1 year. Instruction combines horticultural and environmental topics. Classes include workshops on methods to improve community awareness of environmental issues. The classes stress practical methods for students to become better stewards of their environments on a daily basis. Classes meet

Table 1. Pre- and post-test scores of written exams to evaluate retention of information from the Master Gardener-Environmental and Community Stewardship program.

\begin{tabular}{lcccc}
\hline Year & $\begin{array}{c}\text { Participants } \\
\text { (no.) }\end{array}$ & $\begin{array}{c}\text { Pre-test avg } \\
\text { score/person }\end{array}$ & $\begin{array}{c}\text { Post-test avg } \\
\text { score/person }\end{array}$ & $\begin{array}{c}\text { Change in avg } \\
\text { score/person }\end{array}$ \\
\hline 1993 & 23 & 50 & 69 & +19 \\
1994 & 12 & 38 & 72 & +34 \\
\hline
\end{tabular}

once a week for $2 \mathrm{~h}$ and include formal instruction and interactive question-and-answer periods. Participants are required to contribute $100 \mathrm{~h}$ of volunteer service to share their newly acquired knowledge with their surrounding community.

Instructors include agricultural agents and subjectmatter specialists from extension, Cook College professors from horticultural and environmental sciences, and other selected professionals from across the state. Several farmers in Middlesex County assist extension staff with guided tours of their farms. As part of the MGECS program, volunteers visit local farms to enhance their appreciation and understanding of the challenges faced by the farm community. Farmers share their technical expertise in plant culture with MGECS volunteers and often donate plants and other resources that enhance volunteer projects.

\section{Evaluation}

A written, closed-book pre- and post-test is used to measure each participant's progress. A midterm (closedbook) and a final comprehensive exam are used to track each student's progress. Exams include 60 to 80 questions (true and false, multiple choice, fill in the blank, and essay) that test the range of topics covered in the class. Written evaluations are conducted at the end of each class to measure the effectiveness of the instructor. Pre- and post-surveys are administered to track behavioral and attitudinal changes of program participants. The surveys, consisting of about 60 questions, are given at the beginning and end of the program. In 1994, weekly homework questions were distributed at the end of the class and collected the following week. This encouraged students to review the information covered in the previous class.

\section{Results of the MGECS training program}

The effectiveness of the MGECS training program is described in Table 1. The average increase in post-test scores per person over the first 2 years of the program is 26.5 points. This substantial increase in test scores indicates that students are learning, but the final average scores per person-69 and 72 for 1993 and 1994 respectivelyindicate that there is still room for improvement. Periodic monitoring of the telephone hotline and other volunteer activities by cooperative extension staff indicates that the technical skills of the volunteers have improved during the past 3 years.

A post-survey of the the first year's MGECS class revealed behavioral changes in their use of water, fertilizers, and pesticides in the home and landscape in Spring and Summer 1993 (Table 2). The degree to which behavioral changes can be attributed to program participation is based on changes in individual responses from the pre-test. As indicated from the survey summary (Table 2), it is assumed that" knowledge gained through the MGECS program encouraged $48 \%$ of the participants to increase com-posting activities by $5 \%$ to $25 \%$ and encouraged $57 \%$ of the participants to increase recycling activities by $5 \%$ to $25 \%$. Changes in water, fertilizer, and pesticide use may be attributed to knowledge gained by participants regarding proper cultural management of plants. Participants that previously used a calender approach to pesticide use or watering were now starting to use integrated pest management and watering or fertilizing based on the needs of their landscape plants. The use of least-toxic materials for pest control was emphasized throughout the course.

Comparing the number of volunteer hours returned per person during the first year of participation in the program is an accurate method to track the level of volunteer service encouraged through the MGECS program. As indicated in Table 3, there was a $31 \%$ increase in the average volunteer hours per person in the 1994 MGECS program compared to the traditional MG program offered in 1992. This significant increase in the average volunteer service for participants indicates the ability of the program coordinators to encourage volunteer action through the MGECS program.

Table 2. Percentage of participant in the 1993 Master GadenerEnvivonmental and Community Stewardship program reporting up to a $5 \%$ to $25 \%$ change in the listed activities.

\begin{tabular}{lcc}
\hline Practice & $\begin{array}{c}\text { In-e in activity } \\
\text { (\% of participants) }\end{array}$ & $\begin{array}{c}\text { Decrease in activity } \\
\text { (\% of participants) }\end{array}$ \\
\hline Water use & 5 & 38 \\
Fertilizer use & 24 & 29 \\
Pesticide use & 10 & 24 \\
Comporting & 48 & 0 \\
Recycling & 57 & 0
\end{tabular}

${ }^{2}$ Results from a written survey of 23 program participants in Fall 1993. Participants reported behavioral changes observed during Spring and Summer 1993. Participants did not report changes $>25 \%$. 


\section{Results of volunteer programs in the community}

In Middlesex County, N. J., the MGECS program provides more than $\$ 50,000$ worth of community volunteer service through cooperative extension programs each year. A comparison of total volunteer hours for various activities conducted by participants in the traditional MG program in 1991 to 1992 with those of participants in the MGECS program from 1993 to 1994 is shown in Table 4. Total volunteer hours in the MGECS program from 1993 to 1994 increased by 21.6\% over those in the MG program from 1991 to 1992. This increase indicates that the MGECS program has been highly successful in promoting volunteer service. A discussion of specific volunteer projects follows.

Compost demonstration area. In Spring 1994, MGECS volunteers assisted the cooperative extension staff in establishing a compost demonstration area at the Rutgers Univ. Display Gardens in New Brunswick, N.J. In 1994, more than 150 county residents attended workshops emphasizing proper comporting methods. The primary pur-

increased their comporting activities.

Horticultural hotline and speakers' bureau. Extension-trained volunteers helped to disseminate scientifically based horticultural information through a variety of extension-monitored volunteer activities, including a horticultural telephone hotline, which helped more than 2460 residents, and a speakers' bureau, which reached more than 600 people in the county in 1994 . Volunteers who work on the hotline advise county residents on plant health care practices that encourage least-toxic pest-control methods. MGECS volunteers participate in a speakers' bureau, which provides information to senior citizen groups, garden clubs, and youth organizations.

Community gardening projects managed by MGECS volunteers. The Ozanam Homeless Family Shelter Gardening Project was established in 1991 to provide fresh vegetables during the growing season for homeless single-parent families. Extension volunteers from the MGECS program share their gardening knowledge and experience with staff and residents. In 1994, the garden provided enough produce to feed more than 75 people each day from April through August.

Table 3. Comparison of volunteer hours returned per person during the first year of participation in the traditional Master Gardener (MG) Program in 1991 and 1992 and the new Master GardenerEnvironmental and Community Stewardship (MGECS) Program in 1993 and 1994.

\begin{tabular}{lccc}
\hline Program & Year & No. of participants & Avg volunteer hours/person per year \\
\hline MG & $\mathbf{1 9 9 1}$ & $\mathbf{2 5}$ & $\mathbf{5 9}$ \\
MG & $\mathbf{1 9 9 2}$ & 30 & 63 \\
MGECS & 1993 & 23 & 74 \\
MGECS & 1994 & 12 & 83 \\
\hline
\end{tabular}

Table 4. A comparison of the total number of volunteer hours from Master Gardener (MG) volunteers from 1991-1992 and Master GanEmev-Environmental and Community Stewardship program (MGECS) volunteers from 1993-1994.

\begin{tabular}{lrr}
\hline & \multicolumn{2}{c}{ Totat volunteer hours } \\
\cline { 2 - 3 } Project & $\begin{array}{c}\text { MG program } \\
\mathbf{1 9 9 1 - 9 2}\end{array}$ & $\begin{array}{c}\text { MGECS program } \\
\mathbf{1 9 9 3 - 9 4}\end{array}$ \\
\hline Telephone Q \& A hotline & $\mathbf{2 , 0 8 8}$ & $\mathbf{1 , 6 8 4}$ \\
Community gardening and beautification & $\mathbf{2 , 4 0 0}$ & $\mathbf{3 , 4 0 0}$ \\
Q \& A booths at community events & 400 & 420 \\
Speaker's bureau & 210 & 320 \\
Media and newsletter & $\mathbf{1 , 2 4 8}$ & $\mathbf{1 , 4 4 0}$ \\
Greenhouse & 500 & $\mathbf{9 4 5}$ \\
Office support & 400 & 600 \\
Total & 7,246 & $\mathbf{8 , 8 0 9}$ \\
\hline
\end{tabular}

pose of the compost demonstration area is to encourage home comporting to alleviate the solid-waste crisis in Middlesex County. A pre- and post-survey of people trained by volunteers at the compost demonstration area revealed that $70 \%$ of the 65 respondents on the post-survey increased their comporting activities due to the training they received from MGECS volunteers. There was an $8 \%$ increase in the volume of leaves composted and a $13 \%$ increase in the volume of kitchen scraps and garden waste composted due to program participation. More than $95 \%$ of respondents reported that the compost demonstration area was of benefit to them. The volunteer demonstrations at the display area helped residents learn proper comporting methods and, as a result, residents
The Amandla Crossing Transitional Housing Garden Project provides horticultural and nutritional training, which encourages the use of fresh vegetables produced by homeless single mothers and their families. In 1994, extension volunteers from the MGECS program developed a gardening program, which consisted of eight gardening classes in the spring and included extensive hands-on training sessions. Eight families participated in the garden program and produced enough vegetables to feed themselves and many other families living at the complex.

A third project, The Good Earth Community Gardening project, provides an opportunity for Middlesex County residents to grow their own fresh produce. Many of the participants are apartment dwellers and homeowners with inadequate yard space. Extension volunteers help coordinate the activities of the garden at three sites in the New Brunswick area. In 1994, there were 45 individuals or families with one or more garden plots, and most gardeners produced excess food, which was shared with relatives and friends.

The community gardening programs provide an ideal environment for people to gather and share their harvests and experiences with one another. All of the surrounding residents benefit from a more attractive and productive living environment. On-site coordination by community members, coupled with their active participation in decisionmaking, resulted in community ownership of the programs. 


\section{TECHNOLOGY TRANSFER}

\section{Conclusion}

MGECS program volunteers received adequate technical training in horticulture. The program has encouraged participants to modify their horticultural practices to reflect a greater sensitivity to their surrounding environment. The MGECS program has successfully increased the level and quality of volunteer outreach through cooperative extension guided projects. The establishment of the compost demonstration area by volunteers is an effective method to encourage" county residents to begin home comporting, which reduces the amount of organic materials that end up in local landfills. Volunteers also encourage an integrated approach to plant health care, which reduces excessive or inappropriate applications of fertilizers or pesticides. This is accomplished through lectures, a telephone hotline, and newspaper articles.

Many of the MGECS community gardening and beautification projects have encouraged nontraditional groups of people to work together to provide food, employment, beauty, and hope for those involved. The nurturing of humankind's intrinsic love for plants and gardening may, therefore, provide a nucleus for positive community action and personal environmental stewardship.

\section{Literature Cited}

Bonham, J.B. 1992. Philadelphia green's greene countrie towne model as an agent for community development. In: D. Relf (ed.). The role of horticulture in human well-being and social development: A national symposium. Timber Press, Portland, Ore.

Flagler, J.S. 1992. Master gardeners and horticultural therapy. HortTechnology 2:249-250.

Hlubik, W.T. and H. Betros. 1994. Cultivating people-plant relationships to help nurture environmental stewardship: The Rutgers environmental and community stewardship program. J. Home Consumer Hort. 1(4):373-381.

Master Gardener International Corp. 1991. Directory of master gardener programs in the United States and Canada. Master Gardener Intl. Corp.

Patel, I.C. 1992. Socio-economic impact of community gardening in an urban setting. In: D. Relf (ed.). The role of horticulture in human well-being and social development: A national symposium. Timber Press, Portland, Ore.

Relf D.P. and D. Mckissack. 1992. An evaluation of extension programs to enhance water quality through nutrient management in the urban landscape. HortTechnololgy 2:245-247.

Stainbrook, E. 1973. Man's psychic need for nature. Natl. Parks and Conservation Msg. 47(9):22-23. 